\title{
MYTHICAL BASES FOR A SOCIOLOGICAL DEFINITION OF THE CONCEPT OF CREATIVITY ${ }^{1}$
}

\author{
Juan A. Roche Cárcel \\ Universidad de Alicante
}

\begin{abstract}
The sociological approach to the concept of creativity lacks some accuracy, since it is addressed from an a priori perspective and admitted without reflecting on what it means socially and culturally. In this connection, the present article tries to provide a specific description of the term from its genealogy and on the basis of the socio-cultural-historical context where it arises. More precisely, it deals with the idea conveyed by western myths, the narrative about the identification of the instituting generatrix forces or the procreative divinities that lie behind the birth of the cosmos, of the world, of society, of the earth, of gods, of humans, of animals, and of plants. Thus, from an interpretative examination of the myths about Mother Goddess, those about Biblical Genesis, as well as of Greek creation myths, an attempt will be made to draw a conceptual map that delimits the most defining features of creativity (1). The ultimate goal is to check whether such characters have survived to the present day (2).
\end{abstract}

Keywords: creation myths, creativity, social thought, transdisciplinarity

DOI: https//doi.org/10.3176/tr.2020.2.03

\section{Introduction}

Even though Sociology has traditionally assigned a marginal place to the study of creativity (Joas 2013: 63), the latter has become an emergent research object lately, particularly since Hans Joas published The Creativity of Action in 2013. That is probably why the sociological approach to its concept can be described as somewhat inaccurate, insofar as it is often addressed on an a priori basis and admitted without reflecting on its true social and cultural meaning. Within such a context, this article

\footnotetext{
${ }^{1}$ Translated by Victor Pina, Senior Lecturer University of Alicante.
} 
makes an attempt to provide a more specific definition of creativity from its genealogy and in relation to the socio-cultural-historical environment where it originates. More precisely, it revolves around the way in which creativity is viewed by the western myths which identify the instituting generatrix forces or the procreative divinities that are behind the birth of the cosmos, of the world, of society, of the earth, of gods, of human beings, of animals and of plants. Therefore, an interpretative examination of the myths about Mother Goddess, those about Biblical Genesis, as well as of Greek creation myths will serve as the foundation for drawing a conceptual map meant to define its key features; the ultimate aim consists in verifying the extent to which those features have survived until today.

The theoretical and methodological foundations are supported on M. Weber's civilization stages and on Freud's religious order stages. Nevertheless, given the limited importance that these two scholars assigned both to creativity itself and to the role played by women in it, as well as in civilization, attention will likewise be paid to such influential researchers as M. Gimbutas, J. Campbell, D. Boorstin, G. Steiner and others and, especially, to the postulates of other sociologists who dealt with the evolution of civilization and with the role played therein by religion and family structure.

For Weber, the History of Mankind has developed in three main stages: that of tribal societies and neighborhood ethics; the prophetic or salvation era of fraternity ethics; and the modern individualistic, capitalistic or rationalistic society. Three social agents act successively in the three aforementioned stages - the wizard or shaman; the prophet, the savior, the ascetic and the mystic; and the charismatic man - within a social structure that is rooted in kinship and neighborhood (Bellah 1999: 279-300). The same as Weber, Freud (1985: 37-198) believes - in Totem and Taboo - that family organization, together with the religious factor, constitute the key to historical development. Thus, the paternal horde is replaced by the fraternal clan, in parallel to the substitution of the Son's religion for that of the Father. According to both Weber and Freud, these evolutionary perspectives stem from the religiousfamily structure and they both obviate the role of women, even though Freud (1985: 153) recognizes that totemism is a creation of the 'female spirit'.

The first acknowledgement of a matriarchal order in the Near East and Europe can be found in 1861, in J. Bachofen's Mother Right (Engels 2013: 49). However, it was M. Gimbutas, with her compilation, classification, and descriptive interpretation of nearly two thousand symbolic artifacts coming from European Neolithic sites (7000 B.C. -3200 B.C.) that provided us with the first great systematization of the "Language of the Goddess". This implies a huge historical breakthrough, since it has revealed a philosophy of human existence opposed to the highly ideologized, hierarchized, and manipulated systems which have prevailed on an absolute basis in the Western World during the successive historical periods (Campbell 2015: 387-389).

It thus seems logical - and ethical - to claim that creativity is also feminine and, accordingly, to divide the myths about origin into three distinct areas: that of Mother Goddess - corresponding to a hypothetical matriarchal society -; that of Father God - related to a patriarchal society -; and that of Son God - linked 
to a fratriarchal and democratic era. This tripartite periodization is mentioned by A. Ortiz-Osés (1993) and by a variety of sociologists, including J. Beriain (1999: 7086), J. A. Bergua (2015: 133) and M. Maffesoli (2004: 29, 37, 89), which provides evidence of its obvious sociological relevance. Furthermore - as seen below - it proves very useful in finding the origins of Western creativity, or expressed differently, the creation of our civilization.

Summing up, taking the aforesaid theoretical and methodological bases as our reference, this article is structured around three fundamental sections - respectively dedicated to the genealogy of creativity offered in the myths of Mother Goddess, of Father God, and of Son God - preceded by an introduction and followed by a conclusion.

\section{Mythical genealogy of the concept of creativity}

\subsection{Creativity in the religion of Mother Goddess, the creatrix of the Universe}

\subsubsection{The Goddess of Life and Death: generatrix and nourishing mother and womb for the return of the dead}

The Great Goddess, who stands out as the essential divine figure in the world's first mythological cosmovision (Campbell 2015: 14), originates in the Paleolithic but deploys in the Neolithic. The Paleolithic witnessed the oldest female artistic representations - circular or pear-shaped vulvas, the symbol of sex -(Delporte 1982: 8 and 247, Gamble 2001: 319), which express the conception that hunting societies have about women and divinity and constitute antecedents for the later myths which preserve the old conceptions of the Goddess - first orally and then through writing. A special mention must also be made of the Aurignacian-Gravettian Venuses, small sculptures found in a broad area (France, Italy, Central Europe, Russia and Siberia) (Delporte 1982: 29, 218 and 311). In general, this early naked women-goddesses simultaneously represented the origin itself, the matrix of future mankind as a whole and the omnipresent sex in a wild state (Lessing et al. 1994: 33), without forgetting that they likewise embody an obese and adipose woman-goddess with an idea of abundant beauty, right when surviving was a question of food and fertility (LucieSmith 1994: 11). These Venuses have been located outdoors - where families lived - (Campbell 2015: 19-20), but also inside deep caves, away from the inhabited everyday space (Delporte 1982: 210 and 293-299). It is not by chance that these caves symbolize the vulva, the matrix of Mother Earth and the entry or the return to the maternal uterus (Gimbutas 1991: 233, Gimbutas 1997: 47, Husain 2001: 54 and 163, Smith 2003: 197 and 230-231, and Campbell 2015: 45).

The Goddess of the first farmers developed at a time when the main concerns are no longer animal hunting and slaughter but sowing and harvesting. The oldest images of the Great Goddess of the farming cultures come from the Near East and Europe, and date back to the period between 7000 and 5000 B.C. (Campbell 2015: 25). Nonetheless, the relationships between humans and nature had already deeply 
changed around the year 10000 B.C., after they domesticated it and later dominated it, which in turn brought about a cultural, ideological, and psychical transformation of the human beings themselves (Guilaine and Zammit 2002: 101).

Neolithic religion granted a dominant role to matriarchal symbols, which express the analogy between human and plant fertility and their religious rites (Eliade 1989: 127), as well as the close and mystical bond between the human being and the deep rhythms (Ries 1997: 13), on a permanent evolution, of a nature deified by its cyclical, renovating, and generative potential (Eisenstad 1986: 1-25, Gimbutas 1997: 58). Along with this, the existence of a Pregnant Goddess of Vegetation expresses the idea of a Mother Nature with an impregnated womb, recognizing that the seed is the cause of germination and the reason for the swollen belly of a woman to be assimilated with a sown field. It additionally stresses that the forces of the earth concentrate in mounds, hills, rocks, and trees; and that they associate their matrix with the curvilinear outlines of the land and with the cave (Gimbutas 1991: 233, 1997: 47), the first city, that of the dead (Mumford 1979: 11). Therefore, Mother Goddess embodies life and death and the afterlife that souls emigrate to; it consequently personifies the psychology of mortality and resurrection on which the agrarian mindset is rooted (Bru 1990: 23-25).

In sum, Mother Goddess has two basic functions: it grants life and receives you in death. She is the goddess who gives birth, who takes the seed and turns it into life, but - as the farming peoples knew - the seed grows, develops, matures, dies, and finally returns to the earth from which it came. A third and quite important one for our topic should be added to these two basic functions, though: Mother Goddess inspires poetic realization and the wishes to be not only animals (Campbell 2015: 73-87). In short, the Mother Goddess of matriarchal society is the Creatrix of the Universe and the poetic muse of humans.

\subsubsection{Features of Mother Goddess creativity}

But what are the outstanding characteristics of creativity according to Mother Goddess mythology?

1. The identity between the Creatrix and Creation expresses unity, insofar as creativity is a generating flow that goes from the mother to her children, or from the creatrix to her creations, and vice versa. No breaking of the umbilical cord consequently takes place, since this creativity owns the will to unite what is separated, to erotically merge the opposed strengths born on Earth. Hence why neither divisions nor hierarchies, genders, competitiveness, and conflicts exist in Mother Goddess creativity; and neither does diversity, even though - it must be remembered Mother Goddess diversely manifests herself always remaining unique, as her body represents the cosmos that combines various states of being (Husain 2001: 6-45). Consequently, Mother Goddess entails the illogical - dialectical - coexistence of opposite ends, insofar as she is at the same time the Mother of Mankind, of animals, and of plants; earth and sky, death and renaissance, light and darkness, peace and war (Dunn 2008:14).

2. This merging and erotic creativity is associated with fertility and fecundity, 
related to the woman and the source of life (Flynn 2002: 25), to vital strength. Furthermore, since she is solidly seated on the throne - the Goddess of Çatal Hoyuk, Cybele, Isis and the older Hecate - the same as a mother, she protects and gives security.

3. This explains why Mother Goddess is Nature and her creativity not only stems from it but also returns to it; and hence why the raw material used in her generatrix action is physical, carnal, and corporeal. That is how it should be, Mother Goddess sculpts - as if she were a sculptress - a body which is 'earth' and not 'smoke' and does it through an organic earth teeming with life and enriched by a nourishing humus formed by the decomposed bodies of the dead.

4. The itinerary from life to death which could be described as circular is associated with a creativity that owns a human temporality parallel to nature, since it has a cyclical nature, marked by continuity and governed by the seasons and the passing of days (Duque 2000: 44). It is actually characterized by the phases of the moon - new, full, and waning -, which match the life cycles of the matriarch, of the woman - the maiden, the nymph or nubile woman, and the elderly woman - with the sun seasons - spring, summer, and winter. The time of maternal creation is equally that of the "return to the seed" (Gallego 2003: 379), that of remembrance (Jünger 1998: 68), and that of the periodical return to the past, the one which inspires the feeling of nostalgia for a repeated return to the mythical time of origins (Eliade 1952: 11).

\subsection{Creativity in the religion of Father God and of patriarchal society}

\subsubsection{The Mother's curse and the establishment of Father Creator}

While the civilizations of the Great Goddess of the Near East and Europe essentially obtain their food from farming, nomadic tribes that breed cattle travel across the vast neighboring lands of the Syrian desert, of European and West Asian plains: in the south, Semitic herders of sheep and goats; and in the north, a wide variety of Indo-European peoples. These warrior tribes are not made up of peaceloving and persevering peasants but of nomadic horsemen, whose tutelary gods Marduk, Ashsur, and Yahve amongst Semites - cause thunder and instill fear. In successive waves, from the 4th millennium, these Indo-Europeans move to Mother Goddess areas, where they marry their gods to the local female deities, whereas Semites lay waste to everything that lies in their path from the Syrian-Arab desert to Canaan and Mesopotamia. Indeed, the latter show a much more radical behavior when it comes to the removal of autochthonous goddesses. This actually results in a complete victory of the masculine principle over the feminine one, in such a way that Mother Goddess is reduced to her lowest level: she represents the chaotic, abysmal, and informal cosmic water through the surface of which the human personification of God's shaping spirit moves (Campbell 2015: 30-153).

As opposed to the static and peaceful culture of Mother Goddess, that of Semites is unstable and migrating. Furthermore, their gods are masculine and their cosmos has to do with the celestial sphere and not with the interior of the earth, which is why salvation does not lie in its entrails, but in the ascent to heaven, the symbol of 
the Supreme Father. Added to this, if agrarian religions presented the nudity of the goddess and the sexual act as sacred, religion now moves away from frenzied and orgiastic sensuality, and the sexual act becomes sinful (Bru 1990: 26).

Moreover, Jews' history is marked by almost 2,000 years of exile - as attested by the Bible, which provides an accurate narration of the exodus from Egypt. The diaspora starts in 70 A.D., which means that the banishment lasted over 1,880 years, since it officially came to an end with the foundation of the State of Israel, in 1948 (Hayoun 1995: 201-202). Most interestingly, the Bible is solidly rooted in an earthly story, insofar as it constitutes a drama where the people of Israel play the starring role and dictate the world's fate (Finkelstein and Silberman 2005: 1-16).

\subsubsection{Features of Father God creativity}

1. Yahve, 'the one who makes existence possible', 'the Creator'(Boorstin 2008:44), unlike Mother Goddess, does not start from the visible and sensitive body and, therefore, his creation is not erotic, but rhetorical, since it comes from the mind and, more specifically, from the word, the most important maker of universe (Steiner 2002: 46, Boorstin 2008: 17): "God said, Let there be light, and there was light" (Genesis 1,3-5). This explains why God - and creativity - acquire a non-material, abstract, and exclusively spiritual dimension.

2. Nonetheless, God firstly and paradoxically generates the primary material elements: "In the beginning, Elohim created the skies and the earth" (Genesis 1,1). The state in which the latter found itself before the first day's work consisted in a shapeless mass, with no order whatsoever and without any vegetation, covered by waters and immersed in the darkness, on which the Spirit of God alighted (Monforte s.a). Thus, prior to the organization of the world, only confusion and disorder reigned, tehom, a chaotic mass or primordial matter which - the same as in Mesopotamia (Monforte s.a) - represents a distant echo of the old Mother Goddess, through which the Creator floats. For that reason, an ever-present wild mystery continues to concur in the original creation, at the deepest, in the genesis of every work of art, of any philosophical intuition or of all sorts of creativity, inasmuch as it distils some 'other', inhuman (Steiner 2002: 58).

3. Anyhow, God creates ex nihilo, since there is no pre-existing materiality, which explains why creation does not equal mimesis, which will happen with the Greeks, as shown below.

4. The Creator is the Whole, the complete and full-of-sense being, a Unique, Absolute, Infinite, and Eternal being; and, consequently, his Creation constitutes a unity conceived with utmost care where each detail assumes a function, a characteristic relationship with the whole (Frye 1988: 138). However, if He embodies the homogeneous Whole and the Unity, his Creation conversely represents the part and the difference and, accordingly, his creativity could be based on nothing but differentiation and hierarchization (Frye 1996: 207); this actually explains why angels emerge first, followed by men and, finally, by Nature. Furthermore, the contrast between the created world and the initial chaos predetermines a dual, polarized creativity which opposes day and night, heaven and earth, flesh and spirit, 
world and dream, as well as perfection and imperfection.

5. Polarization, reflection, logic, and linearity precisely shape the masculine methods par excellence (Dunn 2008: 13) and, indeed, when the masculine principle of Father God comes into play, division, separation, and differentiation take place. Instead, the presence of the Mother Goddess feminine principle - as seen above immediately gives rise to union or fusion.

6. The story of Eden attempts to transfer the social power of the pre-Biblical earthly goddess to a symbolically masculine Father God associated with the heavens. The latter is therefore conceived as paternal, in contrast to the maternal Nature, thus transforming the mother into the relative from whom the human being must detach himself in order to be born - physically and spiritually. When she becomes assimilated with Mother Nature, we find a worship of Goddess Earth as the exponent of a human society in a nascent state and 'locked' within a natural cycle of life, death, and renaissance. However, the moment when Adam falls, he is expelled from Paradise, from Nature, which has lost its divine aura (Frye, 1988: 93), and is mythologically defamed - the curse of the earth, adamah, grammatically feminine in Hebrew (Cencillo 1970: 65, 123 and 230); the curse of the snake, the animal of Mother Goddess (Billinghurst 2007: 22); and the condemnation of Eve, the first woman, the guardian of chaos like the ancient Mother Goddess (Frye 1996: 189, 254 and 256, Campbell 2015: 34). Therefore, the whole Old Testament story has an antinatural tone, insofar as it consists in the confrontation between Yahve and the cults of Nature, which implies the most extreme attempt to abolish it.

7. What is more, instead of Nature, the Bible emphasizes the social sphere or social laws, all that has to do with what men do to stay together. In this sense, the social dimension of Father God creativity becomes manifest in the political, 'nationalistic' aspect (Finkelstein and Silberman 2005: IX) of Father God mythology, and not only because it reflects the patriarchal social family structure of Jewish society but also because it constitutes the mythological defense, the idealization of a people forced to be banished from their territory. Hence why - as the Bible says - "There is no God in all the earth, except in Israel" (2 Kings 5:15), a dogma which is in sharp contrast with the meaning of the Goddess, who can be found in every territory and who is any place (Campbell 2015: 34), i.e. a universal, non-ethnic goddess.

8. Along with that social dimension of creativity, the Bible also states its individual power, symbolically masculine as opposed to the communal, which is a feminine creation (Frye 1996: 266). For this reason, the God of Genesis is alive, creative, and personal (Hayoun 1995: 205); and his singularity precisely lies in his power as a maker - as seen above - which means that the peculiarity of human beings, what builds them as such, is therefore their ability to imitate God and his way of exercising the power of creation (Boorstin 2008: 71).

9. Divine creativity was essentially free, since it gave rise to the world by means of a purely volitive act (Hayoun 1995: 201). In fact, the Creator decided to create, and he might have chosen to live in the uncreated infinitude of the void of the neighboring chaos, the only companion during his existence. Thus, biblical creativity always has an optional, contingent, and free nature (Steiner 2002: 136). Deeply linked to this 
divine creative freedom lies its most outstanding creature, the human being, who has actually been endowed with free will by the Creator.

10. Temporality is an invention of Judaism inherited by the Old Testament which constitutes 'the religion of time', a true 'builder of time' (Beriain 2000: 36, 2008: 43). Thus, in the myth of Genesis, the world is created in seven days with a huge effort which leaves God so exhausted that he needs a day's rest. After all, Creation represents a historical event, the prologue to the rest of History (Boorstin 2008: 24 and 71), the absolute beginning and end of time and space (Frye 1988: 96). It is in Genesis that two births created by God - that of cosmos and that of time - are narrated, and where an explanation is given about the process through which we go from the present to the future being; that life - like temporality - results from the nothingness and that history moves. It follows from the above that the world is neither eternal nor immutable; on the contrary, the world is immersed in time and has been created in such a way that it becomes a historical product, a means for human action, that it leaves behind the idle and inactive universe of Paradise (Cioran 1986: VI) and that is determined by uncertainty, insecurity, and freedom (Beriain 2000: 48, 2008: 44-46).

\subsection{Creation in the religion of Father God or of democratic fratriarchal society}

\subsubsection{Greece: from the matriarchal background to the patriarchal one}

The history of Greece develops in three stages from 800 or 750 to 500 B.C. the archaic period -; the 5th and 4th centuries - the classical period -; and, from Alexander the Great to the Roman conquest - the Hellenistic period - (Finley 1975: 29). This history is influenced by the unstable conception of the world and the human being (Castoriadis 1998: 70 and 115, Rodríguez Adrados 1983: 386-422, Mossé 1987: 87, Castoriadis 2006: 10 and 45-358), which possibly incites the Greeks to permanently seek stability, order, and unity. However, together with the desire for the latter, a clear awareness exists about the polarization, the dualism in the world and in society, which leads to classify all beings and things into a series of oppositions. This is typical of a military type of society that owns two historical traditions strongly opposed to one another: the Dorian, which represents the dynamic, individualistic, and centrifugal aspects; and the Ionian, an image of the static, community-based, and centripetal aspects. Added to this, and in correspondence with the above, two socially, culturally, and politically opposed groups exist: the demos; and the aristocracy (Roche 2017).

Faced with that instability, the attachment to the earth arises as one of the most tenacious ways to find a certain degree of stability, since even the economic interests of city dwellers continue to lie in the countryside (Finley 1975: 72). In this connection, agriculture becomes a task linked to economics, but also to religion, society, culture, politics, and war (Gallego 2003: 327). Consequently, despite being an essential feature of peasant households (Garnsey 2003: 90), individualism coexists with the awareness of the need to socialize and to exchange. That is why the origin for the success of oikos - the house - internally derives from a single arrangement of the family group, of the property and of the residence, albeit complemented through the 
external links provided by the exigence of public life (Buxton 2000: 74, Gallego 2003: 70) and commerce. Therefore, the latter, along with agriculture, cattle-raising, manufacturing, and mining played a significant role in the Greek generation of wealth (Mossé 1993: 50-58, Gallego 2003: 200).

The translation into Spanish of polis as ciudad is insufficient, as the former designates a complex human, legal, political, natural, and religious notion (Roche 2017). In any case, it refers to the individual and collective person, insofar as, although the Greeks reveal a clearly individualistic trend, its social conception is fundamentally 'communist' (Kitto 1979: 107); hence why the evolution of the polis the family and the city - (De Coulanges 1986: 116) does not depend on two forces, but on three, since that of the individual must be added to them (Glotz 1957: 4).

Together with the polis, the great Greek creation was Democracy, which has an innate origin in the myth for being linked to the original chaos and the essential instability of human life. But what is exactly understood by democracy, particularly the Athenian one? A suitable answer must take into account its peculiar characteristics and its fundamental principles: law and dike - justice -; isonomy - equality of rights and duties before the law and political participation in the State and in power -; eleuthería - freedom -; isogoría - equality of birth -; isegoría - freedom of speech - and koinonía - community or association; i.e. what is common - (Castoriadis 1998: 117, Gil 1989: 49, Benéitez 2005: 41, Lévêque 1993: 48). It is also necessary to consider the specific format adopted by the Constitution, always in progress and never closed or unmovable (Iriarte 2010: 5), and which offsets power through a central government, an oligarchic council, and a general assembly of citizens (Tilly 2010: 58), as well as its own institutions and the specific aspects which define citizenship and refer both to individual citizens and to collectivity. That is why the alternative between individualism and the idea of community cannot be univocally proposed in democracy, as both things are indissolubly linked (Hauser 1988: 1089).

Speaking about Athenian democracy does not mean referring to equality, though, because contrary to our expectations, it is a slave-owning society, to such an extent that the most important opposition takes place between free individuals and slaves, to which must be added the antagonism existing between citizens and metics, and between the rich and the poor, as well as the one which opposed city dwellers and people who lived in the countryside (Lévêque 1978: 7), without forgetting the sharp distinction between men and women. As a matter of fact, the Indo-European invasions install the prevalence of the masculine principle over the feminine one in Greece, which is why the male will and ego are imposed and progress. Greece thus devises a selfconscious type of masculine intelligence which understands the world rationally and judges it responsibly through empirical facts; and it all - (Campbell 1992, chap. IV) - for the ultimate purpose of developing and maturing the human being, and not of feeling the gods. That entails a markedly patriarchal social structure based on marriage and private property (Mossé 2001:150).

This explains why Mother Goddess no longer constitutes the focus of worship and why she is replaced by the Olympic masculine gods in the main pantheon. Furthermore, the old divinity undergoes a mythological defamation with Zeus' 
victory against Typhoon or that of Apollo over Python, which symbolize the triumph of a new masculine justice order over the archaic, 'agitated' and 'chaotic' matriarchal power (Iriarte and González 2008: 123). The influence exerted by Mother Goddess does not disappear, though, since it will survive by segmenting her competences between different goddesses that personify one of her aspects - Demeter, Hera, Aphrodite, Artemis, and Athena. Nonetheless, despite continuing to symbolize the natural life of animals, plants and mankind, the affirmation of courage, fertility and erotic love, they now represent the home and the bond between women and men (Dunn 2008: 30). Not in vain, the Olympic pantheon has been organized through the adoption as a model of the family and patriarchal hierarchical structure of the new Indo-European society which is superimposed upon the atavistic matriarchal one.

\subsubsection{The diverse Greek creation myths}

Aristotle carries out a summary of the various old Greek theogonies (Metaphysics, 1091a-1092a), but, for the purpose of this article, our attention will especially focus on three different and contradictory paradigms about creation:

1. Homer's 'world without beginning', which has no interest in the origin of the world, since it revolves around human adventures and anthropomorphic gods instead. Furthermore, the humans and divinities in the Iliad and the Odyssey have reached their full maturity and, most outstandingly, it is Man and not creation that constitutes the starting point (Boorstin 2008: 35-42).

2. The 'intuition of a void prior to being'. In Hesiod's Theogony, creation is erotic, which entails a birth that leads to life, eternally renewed with creativity (Steiner 2002: 45, 95 and 264). This means that it reveals innumerable acts of creation (Boorstin 2008: 43) - an echo of Mother Goddess and of her successive restarts and additionally refers to the feats of gods and not to the genesis of the world (Arendt 2005: 92). More precisely, Kháos seems to be the matrix of everything that has been created, the origin of all things, a bottomless, vast and dark, confusing and gloomy void, and a shapeless and undifferentiated place (West 1966: 192-193, Chantraine 1999: 1246) from which the first deity arose, Gea 'the broad-breasted one', Mother Earth, the 'permanently safe seat', 'the ground of the world', the goddess of 'solid foundations', as highlighted in the Homeric Hymn to the Earth, 1. Therefore, Nature, Divinity, and Men emerge from the unspeakable chaos and they are all consequently 'children of the abyss', unceasingly fighting against it.

The fight also characterizes the whole created order and seems to be immanent to the actual generation process. It is worth noting, in this respect, that the emergence of divinities entails universal suffering, and that it takes place to fight the forces of disorder and to find - each time and definitively - the order and unity that their differentiation and individuality broke (Vernant 2001: 41, Vernant 2003: 15). Consequently, this old mythical awareness of the impossibility to solve the problem of world disorder will appear once and again in every social and cultural activity, and at any time (Castoriadis 2006: 10 and 45-358).

3. The search for the original unity. According to Parmenides, nothingness does not exist, and it is impossible to think about it (Steiner 2002: 35). Indeed, he 
understands - unlike Hesiod - that there is an identity between being and thinking, insofar as being is not nothingness, and does not originate from it either, and neither does it return into its heart: "....since there is being, nothingness does not exist" (Poem II, fragment 6, 1). Starting from this idea, Plato (Ion) points out that the artist is not a primary creator (Steiner 2002: 61); instead, he defends (Timaeus, 30) that a chaotic substratum exists in the universe and, therefore, the demiurge - the craftsman who makes the world - knows that he cannot fully rationalize the cosmos that he is building. This fits in with Plato's deep mistrust in the human being, due to the outcomes derived from the process of History and to rationality, which he considers insufficient to achieve his main objective: the search for unity and for the absolute (Muñoz 1975: 77). In contrast, the philosopher suggests (Timaeus) that the world is formed with pure ideas and impure immaterial substances and that, rather than a creator, there are recreation cycles (Boorstin 2008: 52).

\subsubsection{The common features of creativity}

In addition to the specific factors that generated the creation myths dealt with here, the Greeks generally assign the following characters to creativity:

1. Creativity essentially follows the masculine principle, even though the feminine one survives and even becomes powerfully present in certain moments and circumstances. For instance, although the Iliad portrays the masculine IndoEuropean world, 'the Goddess returns' in the Odyssey, since Ulysses' itinerary may constitute a visionary journey to reintegrate the masculine and the feminine as well as the reciprocity of their relationship (Campbell 2015: 221 and 247).

2. Thus, Greek creativity, dominated by the masculine principle, is determined by a deep polarization that materializes in an opposition between the collective and the individual sphere, between unity and diversity, between logos and irrationality, between matter and idea, and between immanence and transcendence. Greek creativity thus moves between the collective and the individual sphere - in theatre (Kitto 1979: 122, Duvignaud 1966: 242) and in art (Fischer 1986: 53, Finley 1975: 159, Buxton 2000: 68, Bowra 1983: 123, Boardman 1988: 311-341, Tatarkiewicz 1987: 345, Blanco Freijeiro 1990: 334).

3. Likewise, creativity reveals a deep tension between unity and diversity. Thus, artists were divided into two opposed schools already during the Archaic Age: the Dorian and the Ionian culture, which oscillate between fiction and truth, between imitation and creation, and between Beauty and convenience. In short, Greek Antiquity knows and appreciates a twofold beauty: that of symmetry; and the individual one of convenience (Tatarkiewicz 1987).

4. Logos and irrationality are inherent to the Greek creativity process. The noun logos - as stressed by Heidegger in the Introduction to Metaphysics - derives from the verb légein, which means 'to speak', 'to refer', 'to select', 'to bring together', 'to assemble'. Therefore, all these actions suggest that logos - the same as creativity - refers us back to a way of thinking, of counting or calculating, and of relating (Bilbeny 2012: 86). Furthermore, "the oldest term for the kingdom of the word conceived like this, to say, is called logos... the word logos itself, the name for 
saying, is simultaneously used for being, i.e. for the presence of what is present" (Heidegger 1987: 213), which means that language - and creativity - are home to being (Trías 1984: 97-98).

However, if rationality is one of the essential characteristics of creativity, so is irrationality, insofar as powerful irrational forces of an external or internal origin exist in Greece, namely: mania, madness, ATE, the fear of Miasma and of contamination, Phthónos, the envy of gods, the continued existence of demons and, finally, the fear of freedom which characterizes the whole Hellenistic period; and the goddess of fortune Tyché who, with her swings, batters humans in such a way that her actions including the creative ones -, rational as they might be, carry a wild and unexpected component with themselves; they trigger unforeseen consequences (Dodds 1983).

5. Greek art is material, and at the same time, ideal (Flynn 2002: 35). In this connection, as stated by Plato (Cratylus 430a), both word and image must transmit the fundamental qualities of the idea underlying them (Böhme 2000: 178-200).

6. The key esthetic concept for the Greeks is that of mimesis or imitation, which means that, rather than creation, this has to do with recreation, by means of which the artist or the philosopher reflect on what exists (Steiner 2002: 32).

7. Creativity in Greece basically develops within space and not over time, since the interpretation of being neither knows nor understands the fundamental ontological function of time (Heidegger 2003: 49), forgets about it in religious representations (Kerényi 2010: 78) and limits it, so that human existence can progress inside it (Glacken 1996: 52).

Greek creativity would thus arguably lie closer to the spatial category than to the temporal one (Beriain 2008: 43), because the Greeks were not expelled from paradise and deeply loved their territory; hence why - like the Egyptians - they were 'builders of space' - so is Greek creativity -; they filled the natural 'voids' and urbanized nature (Beriain 2000: 36). Nonetheless, this space devoid of time is not - as that of Mother Goddess was - absolute and infinite but constrained by measures and limits.

\section{Conclusions}

\subsection{Creativity and the cultural continuity with the past}

After analyzing and interpreting the myths about the origin of Mother Goddess, those about biblical Genesis, and the old Greek myths - which correspond to three types of religiousness and to the same number of societies - and from the objectives proposed, a conceptual map of creativity has been drawn which allowed me to define the most important characters unveiled by those myths.

More specifically, it was possible for me to obtain a number of variables organized on a polar basis which set the limits of creativity and make it possible to show its different orientations towards fusion or differentiation, space or time, the vital or the spiritual sphere, the feminine or the masculine, the body or the mind, the collective or the individual sphere, security or risk, chaos or order, freedom or necessity, and creativity or mimesis. 
Broadly speaking, those pairs either have merged or have become polarized in the three mythical stages, albeit not in an absolute manner. Matriarchal society, for example, is characterized by the fusion of concepts into a whole, although it has been steadily incorporating aspects related to invasive masculine divinities that have contaminated its old essences. In turn, patriarchal society follows a deeply and vehemently polarizing approach - anti-feminine and anti-natural. Finally, the unstable fratriarchal and democratic society, despite adopting a polarizing attitude too, is not so radical in its ruptures, as one of the poles becomes the dominant one, while the other assumes a subordinate role without completely disappearing.

Amongst postmodern tribes, there seems to be a certain revival of the Great Mother Goddess (Maffesoli 2004: 89-145), because of her characteristic corporeality (Joas 2013: 214), for her emotional and amorous fusion, and for her vital power, as well as for her fertile energy that creates new ways of living. Life has thus become a collective work of art (Maffesoli 2004: 44-183), the great creation, which refers us back to Mother Goddess cosmovision, but also to that of Father God, insofar as life overflows and transcends itself (Simmel 2014: 1 and 24) and gives rise to moments of both religious (Nocera 2009: 101) and revolutionary effervescence (Durckheim 1993: 348-349). However, neither should we forget the teaching of nineteenthcentury philosophical vitalism which has reminded us that, at present - both the market and the advertising sector are well aware of it - life remains unsatisfied and restless, that it constitutes an unattainable and illusory goal, which leaves us deeply empty.

However, the presence of Father God also becomes visible in today's society. The 'economy of access' (Rifkin 2000: 50), contemporary art (Guasch 2002), and the virtuality of new technologies are rooted in the conceptualism of biblical creativity, just as the innovation of technological and financial enterprises does when their creativity causes growing inequality (Ariño 2016: 62-94). At the same time, the spirit of Yahve is present in the ambivalent individual and collective creativity of charisma or genius. The charisma of extraordinary figures (Weber 1984: 241) generates a new order opposed to the traditional one, whereas genius may certainly have a feminine nature (Tönnies 2011:273), but can likewise be a male individual whose creativity is determined by the social process to such an extent that he can even be defeated by it (Elias 1991: 74). Democracy drives freedom as well as personal and social creativity, because it represents an ongoing self-creation of social action (Dewey 1996: 227232, Touraine 1995). Finally, biblical time comes to its close in the multifaceted, random, and constructed postmodern identity, a life project (Nair et al. 1999: 77, Sennet 2000: 140, Bauman 2003: 88).

The Greek way of understanding creativity has left its footprint at present in the problematic conception of human nature, in unstable and fragile human beings marked by chaos in their infrastructure (Morin 1981, 76). This fragility and instability ultimately take us back to the notions of 'contingency', 'uncertainty', and 'risk' (González 2006: 389 and 408 ), as well as to lighter and weaker ties (Illouz 2009: 205). Likewise, the Greeks' spatial construction can currently be felt in creative cities (Florida 2009: 74-213) or in offices (Bergua et al. 2016: 38), where economic 
growth, the exchange of news, and happiness take place. It is as if the city or the workplace became the safe and merging mother or the Paradise from which we were never expelled.

All in all, creativity currently generates a society that is simultaneously feminine and masculine, merging and differentiating, corporeal and spiritual, material and conceptual, individual and collective, secure and risky, free and necessary. Life in it is full or empty and, consequently, creativity moves between being and nothingness, between the inheritance left by Mother Goddess and those of Father God and Son God. This confirms not only that cultural continuity exists but also that nothing is definitively lost (Bellah 2005:72).

\subsection{Creativity builds the autonomous individual and society}

In any case, creativity is on the one hand inherent to autonomous individuals, to 'legally-of-age beings' - the great Kantian enlightened ideal, not completely lost, despite its successive failures - since it produces individual, unique and unrepeatable, 'original', rational and emotional, feeling and thinking beings - the psychological function of creativity. This explains why one's own personal life is concocted by means of creativity and freedom (the Bible, Greece, democracy), with nobody imposing the lifestyle or the actual meaning of existence on anybody else. Notwithstanding, an unshared, non-erotic type of creativity, not conceived as a common issue - in short, not socialized - does not seem possible, insofar as it once again reminds us that the human being is either social or unsocial. Creativity performs a first-order sociological function, since it edifies personal biographies and helps found history, thus playing an essential historical role too.

\section{Acknowledgements}

I thank professors Francisco Díez de Velasco, Professor of History of Religions at the University of La Laguna, Josetxo Beriain, Professor of Sociology of Religion at the Public University of Navarra and José Á. Bergua Amores, Professor of Sociology at the University of Zaragoza review, suggestions and criticisms of this article.

Address

Juan A. Roche Cárcel

Universidad de Alicante

Departamento de Sociología I

Carretera de San Vicente del Raspeig, s./n, 03690

San Vicente del Raspeig

Spain

E-mail: Ja.Roche@ua.es 


\section{References}

Arendt, H. (2005) La condición humana. Barcelona: Paidós.

Ariño, A. (2016) La secesión de los ricos. Barcelona: Galaxia Gutenberg.

Bauman, Z. (2003) Modernidad líquida. Buenos Aires: FCE.

Beck, U. and E. Beck (2008) El normal caos del amor. Las nuevas formas de la relación amorosa. Barcelona: Paidós.

Bellah, R.N. (2005) "What is axial about the Axial Age?". Archives Européennes de Sociologie 46, 1: 69-87.

Benéitez, B. (2005) "La ciudadanía de la democracia ateniense". Foro Interno 5: 37-58.

Bergua, J. A. (2015) Postpolítica. Elogio del gentío. Madrid: Biblioteca Nueva.

Bergua, J. A., E. Carretero, J. M. Báez, and D. Pac (2016) Creatividad. Números e imaginarios. Madrid: CIS.

Beriain, J. (1999) "Del reino de Jaungoikoa (Dios) al politeísmo moderno". In J. Beriain and R. Fernández Ubieta, eds. La cuestión vasca, 70-86. Barcelona: Anthropos.

Beriain, J. (2000) La lucha de los dioses en la modernidad. Del monoteísmo religioso al politeísmo cultural. Barcelona: Anthropos.

Beriain, J. (2008) Aceleración y tiranía del presente. La metamorfosis en las estructuras temporales de la modernidad. Barcelona: Anthropos.

Billinghurst, J. (2007) Mujeres tentadoras. Barcelona: Océano.

Bilbeny, N. (2012) Ética. Barcelona: Ariel.

Blanco Freijeiro, A. (1990) Arte griego. Madrid: C.S.I.C.

Boardman, J. (1988) Arte y arquitectura griegos. In Historia Oxford del mundo clásico. Vol. 1: Grecia, 311-353. Madrid: Alianza.

Bohme, G. (2000) Platons theoretische Philosophie. Stuttgart and Weimar: Metzler.

Boltanski L. and É. Chiapello (2002) El nuevo espiritu del capitalismo. Madrid: Akal.

Boorstin, D. J. (2008) Los creadores. Barcelona: Crítica.

Bowra, C. M. (1983) La Atenas de Pericles. Madrid: Alianza.

Bru, M. (1990) "La mujer en el arte prehistórico. Simbología y Representación”. Actas de las Terceras Jornadas de Investigación Interdisciplinar, 17-28.

Buxton, R. (2000) El imaginario griego. Los contextos de la mitología. Madrid: Cambridge University Press.

Calonge, J., E. Acosta, F. J. Olivieri, and J. L. Calvo (2000) Introducciones, traducciones y notas, Platón, Diálogos. Vol. 2: (Gorgias, Menéxeno, Eutidemo, Menón, Crátilo). Madrid: Gredos.

Calvo, T. (2000) Introducción, traducción y notas, Aristóteles, Metafísica. Madrid: Gredos.

Campbell, J. (2015) Las Máscaras de Dios: Mitología Occidental. Madrid: Alianza.

Campbell, J. (1992) Diosas. Girona: Atalanta.

Cárcel, J. A. (2017) Entre el Monte de Apolo y la vid de Dioniso. Naturaleza, Dioses y Sociedad en la arquitectura teatral de la Grecia Antigua. Barcelona: Anthropos.

Castoriadis, C. (1998) La polis griega y la creación de la democracia. In Los dominios del hombre. Las encrucijadas del laberinto, 97-132. Barcelona: GEDISA.

Castoriadis, C. (2006) Lo que hace a Grecia. Vol. 1: De Homero a Heráclito. Seminarios 1982-1983. La creación humana II. Buenos Aires: F.C.E.

Cencillo, L. (1970) Mito. Semántica y realidad. Madrid: Biblioteca de Autores Cristianos.

Cioran, E. M. (1986) La caída en el tiempo. Barcelona: Planeta Agostini. 
Chantraine (1999) Dictionnaire étymologique de la langue grecque. Histoire des mots. Paris: Klincksieck.

De Coulanges, F. (1986) La ciudad antigua. Madrid. Biblioteca EDAF.

Delporte, H. (1982) La imagen de la mujer en el arte prehistórico. Madrid: Colegio Universitario de ediciones Istmo.

Dewey, J. (1996) Democracia creativa: la tarea ante nosotros. In Liberalismo y otros ensayos, 199-205. Valencia: Edicions Alfons El Magnànim.

Dodds, E. R. (1983) Los griegos y lo irracional. Madrid: Alianza.

Duque, F. (2000) Filosofía para el fin de los tiempos. Madrid: Akal.

Dunn Mascetti, M. (2008) Diosas. La canción de Eva. El renacimiento del culto a lo femenino. Barcelona: Malsinet editor, colección Nueva mujer.

Durán Ma . Á. and Lisi, F. (2000) Introducciones, traducciones y notas, Platón, Diálogos. Vol. 6: (Filebo, Timeo, Critias). Madrid: Editorial Gredos.

Durckheim, É. (1993) Las formas elementales de la vida religiosa. Madrid: Alianza.

Duvignaud, J. (1966) Sociología del teatro. Ensayo sobre las sombras colectivas. México: FCE.

Eisenstand, S. N. (1986) "The Axial Age breakthroughs - their characteristics and origins". In The origins and diversity of Axial Age civilizations, 1-29. State University of New York.

Eliade, M. (1952) El mito del eterno retorno. Buenos Aires: EMECE.

Eliade, M. (1989). Herreros y alquimistas. Madrid: Alianza.

Elías, N. (1991) Mozart. Sociología de un genio. Barcelona: Península.

Engels, F. (2013) El origen de la familia, la propiedad privada y el Estado. Alianza: Madrid.

Finkelstein I. and N. A. Silberman (2005) La Biblia desenterrada. Una nueva visión arqueológica del antiguo Israel y de los orígenes de sus textos sagrados. Madrid: Siglo XX.

Finley, M. I. (1975) Los griegos de la Antigüedad. Barcelona: Nueva Colección Labor.

Fischer, E. (1986) La necesidad del arte. Barcelona: Planeta-Agostini.

Flynn, T. (2002) El cuerpo en la escultura. Madrid: Akal.

Florida, R. (2009) Las ciudades creativas. Por qué donde vives puede ser la decisión más importante de tu vida. Barcelona: Paidós.

Freud, S. (1985) Tótem y Tabú. Bilbao: Alianza editorial-Club Internacional del Libro.

Frye, N. (1988) El Gran Código. Barcelona: GEDISA.

Frye, N. (1996) Poderosas palabras. La Biblia y nuestras metáforas. Barcelona: Muchnik.

Gallego, J. (2003) “Comunidad aldeana y sociabilidad campesina en la Grecia Antigua”. In J. Gallego, ed. El mundo rural en la Grecia antigua, 327-380. Madrid: Akal.

Gamble, C. (2001) Las sociedades paleolíticas de Europa. Barcelona: Ariel.

García, J. (2001) Introducción general and Bernabé, A. traducción y notas, Homero, Himnos Homéricos. La 'Batracomiomaquia'. Madrid: Biblioteca Clásica Gredos.

Garnsey: (2003) "El campesinado: subsistencia y supervivencia”. In J. Gallego, ed. El mundo rural en la Grecia antigua, 71-102. Madrid: Akal.

Gil, L. (1989) "La ideología de la democracia ateniense”. Cuadernos de Filología Clásica 23, 30-50.

Gimbutas, M. (1991) Diosas y dioses de la vieja Europa. Madrid: Ediciones Istmo.

Gimbutas, M. (1997) "La religiosidad de la Diosa en la Europa Mediterránea". In Tratado de Antropología de lo sagrado: las civilizaciones del Mediterráneo y lo Sagrado, 41-62. Madrid: Trotta. 
Glacken, C. J. (1996) Huellas en la playa de Rodas. Naturaleza y cultura en el pensamiento occidental desde la Antigüedad hasta finales del siglo XVIII. Barcelona: Ediciones del Serbal.

Glotz, G. (1957) La ciudad griega. México: Unión tipográfica Hispano Americana.

González, J. M. (2006) La diosa Fortuna. Metamorfosis de una metáfora política. Madrid: Antonio Machado libros.

Guasch, A. M. (2002) El arte último del siglo XX. Del posminimalismo a lo multicultural. Madrid: Alianza.

Guilaine J. and J. Zammit (2002) El camino de la guerra. La violencia en la prehistoria. Barcelona: Ariel.

Hauser, A. (1988) Historia social del arte y de la literatura. Barcelona: Labor.

Hayoun, M. R. (1995) "El judaísmo". In J. Delumeau, ed. El hecho religioso. Enciclopedia de las grandes religiones, 201-252. Madrid: Alianza.

Heidegger, M. (1987) De camino al habla. Barcelona: Delós.

Heidegger, M. (2003) Ser y tiempo. Madrid: Trotta.

Husain, S. (2001) La Diosa. Creación, fertilidad y abundancia. Mitos y arquetipos femeninos. Colonia: Taschen.

Illouz, E. (2009) El consumo de la utopía romántica. El amor y las contradicciones culturales del capitalismo. Madrid: Katz.

Iriarte, A. (2010) “Atenas o el arte de lo político”. Revista Bitarte 50, $29-42$.

Iriarte A. and M. González (2008) Entre Ares y Afrodita. Violencia del erotismo y erótica de la violencia en la Grecia Antigua. Madrid: Abada editores.

Joas, H. (2013) La creatividad de la acción. Madrid: CIS.

Jünger, E. (1998) El libro del reloj de arena. Barcelona: Tusquets.

Kerényi, K. (2010) Imágenes primigenias de la religión griega. II. Hermes el conductor de almas. El mitologema del origen de la vida masculina. México: editorial Sexto Piso.

Kitto, H.D.F. (1979) Los griegos. Buenos Aires: EUDEBA.

Lessing, E. and Ph. Sollers (1994) Mujeres, mitologías. Barcelona: M Moleiro editor.

Lévêque (1978) Las diferenciaciones sociales en el seno de la democracia ateniense del siglo V. In D. Roche, ed. Órdenes, estamentos y clases. Madrid: Siglo XXI.

Lévêque (1993) "El papel de la religión en la génesis de las ciudades". In Revista de Occidente 143, 43-60.

Lucie-Smith, E. (1994) La sexualidad en el arte occidental. Barcelona: Destino.

Llansó, J., ed. (2007) Parménides, Poema, Madrid: Akal.

Maffesoli, M. (2004) El tiempo de las tribus. Elocaso del individualismo en las sociedades posmodernas. México: Siglo XXI.

Monforte, J. M. (s.a). La Biblia y el sentido del Universo. Biblioteca Católica Digital. Available online at $<$ www.almudi.org $>$. Accessed 30 January, 2018.

Morin, E. (1981) El método I. La naturaleza de la naturaleza. Madrid: Cátedra.

Mossé, C. (1987) Historia de una democracia: Atenas. Madrid: Akal.

Mossé, C. (2001) La mujer en la Grecia clásica. Madrid: Nerea.

Mumford, L. (1979) La ciudad en la historia. Buenos Aires: Infinito.

Muñoz, I. (1975) "La ideología de la aristocracia griega antigua". Revista de Estudios Políticos 199, 65-82. 
Nair, S. and J. de Lucas (1999) Inmigrantes. El desplazamiento en el mundo. Madrid: Ministerio de Trabajo y Asuntos Sociales. Secretaría General de Asuntos Sociales. Instituto de Migraciones y Servicios Sociales.

Nocera (2009) Los usos del concepto de efervescencia y la dinámica de las representaciones colectivas en la sociología durkheimiana. REIS 127, 93-119.

Ortiz-Osés, A. (1993) Las claves simbólicas de nuestra cultura: Matriarcalismo, patriarcalismo y fratriarcalismo. Barcelona: Anthropos.

Rifkin, J. (2000) La era del acceso. La revolución de la nueva economía. Barcelona: Paidós.

Ries, J. (1997) Tratado de antropología de lo sagrado: las civilizaciones del Mediterráneo y lo sagrado. Madrid: Trotta.

Rodríguez Adrados, F. (1983) La Democracia ateniense. Madrid: Alianza.

Sennet, R. (2000) La corrosión del carácter. Las consecuencias personales del trabajo en el nuevo capitalismo. Barcelona: Anagrama.

Simmel, G. (2014) Intuición de la vida. Prometeo: Buenos Aires.

Smith, P. (2003) Arte rupestre paleolitico en Cantabria. Santander: Asociación Cántabra para la defensa del patrimonio Subterráneo.

Steiner, G. (2002) Gramáticas de la creación. Siruela: Madrid.

Tatarkiewicz, W. (1987) Historia de la Estética. I. La estética antigua. Madrid: Akal.

Tilly, Ch. (2010) Democracia. Madrid: Akal.

Tönnies, F. (2011) Comunidad y asociación. El comunismo y el socialismo como formas de vida social. Madrid: Biblioteca Nueva-Minerva.

Touraine, A. (1995) Producción de la Sociedad. México: Instituto de Investigaciones Sociales UNAMIFAL.

Trías, E. (1984) Drama e identidad. Barcelona: Ariel.

Vernant, J.-P. (2001) El individuo, la muerte y el amor en la Antigua Grecia. Barcelona: Paidós.

Vernant, J.-P. (2003) El universo, los dioses, los hombres. El relato de los mitos griegos. Barcelona: Anagrama.

Weber, M. (1984) Economía y Sociedad. Esbozo de sociología comprensiva. Mexico: F.C.E.

West, M. L. (1966) Hesiod Theogony. London: Oxford University Press. 